\section{Fibrous PCL scaffolds as tissue substitutes}

\author{
Luciana P. Giorno ${ }^{1 *}$; Leonardo R. Rodrigues; Arnaldo R. Santos Jr ${ }^{1}$ \\ ${ }^{*}$ Corresponding author: e-mail address: giorno.l@ufabc.edu.br
}

Abstract: Burns are characterized by high clinical complexity. Large skin wounds reduce the body's defenses and activate the inflammatory cascade, resulting in complications such as multiple organ dysfunction syndrome. In an attempt to improve techniques for burn management, tissue engineering has emerged as a viable alternative in which biocompatible materials are used to mimic the extracellular matrix. Scaffolds were fabricated using a poly( $\varepsilon$-caprolactone) polymer matrix (PCL) and PCL combined with gelatin. The solutions were submitted to rotary jet spinning and then crosslinked. All materials were characterized following recommended technical standards (biological and physical). The results showed satisfactory homogenization of the solutions. We observed the formation of PCL and PCL/gelatin fibers. Fourier-transform infrared spectroscopy confirmed the material used in the scaffolds. In conclusion, rotary jet spinning was found to be effective for fiber production and the scaffolds obtained were non-toxic

Keywords: Burns. Biocompatible Materials. Rotary Jet Spinning.

\section{Introduction}

Burns are a public health problem of high clinical complexity and are associated with prolonged hospital stay, immune system disorders susceptibility to infections, and high morbidity and mortality. ${ }^{1,2}$ Depending on the extent and characteristics of the burn injury, skin transplantation is the gold standard treatment to ensure patient survival because of the limitations of the tissue repair process. ${ }^{3,4}$ However, the imbalance between effective organ donors and recipients indicated by the National Transplant System has encouraged the search for therapeutic alternative to overcome this shortage. , $^{3,4,5}$

Among emerging technologies, tissue engineering is a field aimed at elucidating the structure-function relationship between normal and diseased tissues in order to repair or replace tissue using bioresorbable scaffold with specific physical characteristics that mimic human morphofunctionality. Mimicking human tissues, the physiological reactions in response to biomaterials are expected to favor the good integration of these materials in the organism. Thus, research constantly seeks to change the surface of materials in order to improve the capacity of cell adhesion, growth, proliferation and differentiation in the tissues for which they are destined. $6,7,8,9,10,11$

Poly $(\varepsilon$-caprolactone) (PCL) is a bioresorbable material that was approved by the Food and Drug Administration (FDA) for use in humans $\mathrm{PCL}$ is characterized by properties such as flexibility, good mechanical strength, and moderate undesirable host reactions. In addition, $\mathrm{PCL}$ is compatible with a wide range of other polymers and is a candidate for grafting and for stimulating cell regeneration. ${ }^{12,13}$ Gelatin, which is derived from collagen, is widely used in tissue engineering and cell culture, representing a common substrate for cells. ${ }^{14}$

We aimed to develop a polymer scaffold (PCL/gelatin) via rotary jet spinning that can be used in the future for the filling and repair of injured tissues.

\section{Materials and methods}

\section{Materials}

CAPA 6500 PCL [Aldrich 440744-250G, Mn 70000-90000; reported molar mass of 50,000 grams per molecule $(\mathrm{g} / \mathrm{mol})]$ and gelatin from bovine skin [Sigma-Aldrich, CAS Number: 9000-70-8 MDL: MFCD00081638;
Type B] were used. The $\mathrm{pH}$ of a $1.5 \%$ solution ranges from $5.0-7.5$ at $25^{\circ} \mathrm{C}$.

\section{Sample Preparation}

PCL was dissolved in chloroform (Vetec Química) and stirred in a magnetic stirrer (model 753A, Fisatom) for $24 \mathrm{~h}$. The homogenized solution was transferred to the rotary jet spinning chamber. ${ }^{15,16,17}$ The formation of fibers was observed by the flow of the polymeric solution in the collector through capillaries on the lateral surface of the equipment using a maximum power of $950 \mathrm{~W}$ and a motor of 210/3,400 (W/rpm). ${ }^{18}$ After solvent evaporation, the fibers were removed from the collector and stored in a desiccator before use. Gelatin was dissolved at 20\% in distilled water at $\pm 60^{\circ} \mathrm{C}$ under constant agitation (magnetic GO stirrer MS-H-Pro) for $20 \mathrm{~min}$. Next, 1\% glutaraldehyde solution (Sigma-Aldrich) was added and the mixture was incubated for $24 \mathrm{~h}$ to permit crosslinking. For the PCL/ gelatin scaffold, PCL and gelatin were prepared as described above. The PCL fibers were immersed in gelatin solution, followed by glutaraldehyde also as described above. ${ }^{14,19}$

The crosslinked gelatin and PCL materials were disinfected with $70 \%$ ethanol for $24 \mathrm{~h}$ and kept in medium 199 (Lonza) without fetal bovine serum (FBS) in an incubator for $24 \mathrm{~h}$ at $37^{\circ} \mathrm{C}$ (ISO-10993-5). The PCL/ gelatin scaffold was sterilized by autoclaving (Stermax) at a pressure of $15 \mathrm{lbs}$ and temperature of $121^{\circ} \mathrm{C}$ for $\pm 20 \mathrm{~min} .{ }^{20}$

\section{Morphological Characterization of the Scaffolds by Light Microscopy}

The samples were examined under a phase-contrast inverted light microscope (Axio Vert.A1, Zeiss) for analysis of the fibers produced by rotary jet spinning. Fragments of the materials were mounted between a slide and coverslip. Drops of distilled water were used to reduce light refraction and to improve resolution. ${ }^{21}$

\section{Characterization of the Scaffolds by Fourier-Transform Infrared Spectroscopy (FTIR)}

The functional groups and characteristic vibrational modes of each polymer were evaluated with the Spotlight 400 FTIR Imaging System. The parameters adopted were a measurement range of 4000 to $500 \mathrm{~cm}^{-1}$ using the attenuated total reflectance (ATR) technique in the transmittance mode,

${ }^{1}$ Centro de Ciências Naturais e Humanas (CCNH), Universidade Federal do ABC, São Bernardo do Campo, SP, Brazil.

${ }^{2}$ Centro de Engenharia, Modelagem e Ciências Sociais Aplicadas (CECS), Universidade Federal do ABC, Santo André, SP, Brazil. 
with a resolution of $1 \mathrm{~cm}^{-1}$ in four scans per measurement. ${ }^{22}$

\section{Cell Culture}

Vero cells, a cell line established from African green monkey (Cercopithecus aethiops) kidney cells, were used. These cells were cultured in medium 199 (Lonza) with 10\% FBS (Nutricell Cellular Nutrients, Campinas, SP, Brazil) at $37^{\circ} \mathrm{C}$ in an incubator with $5 \% \mathrm{CO}_{2}$. The medium was changed whenever it was acidified and subcultures were obtained once or twice a week. Vero cells are recommended for studies of cytotoxicity and cell-cell interactions on biomaterials. ${ }^{23,24}$

\section{In Vitro Direct Contact Toxicity}

Fragments of each material (PCL, gelatin, and PCL/gelatin) were placed in 24-well culture plates and incubated in FBS-free medium for $24 \mathrm{~h}$ at $37^{\circ} \mathrm{C}$ in a $5 \% \mathrm{CO}_{2}$ atmosphere. After this period, Vero cells were inoculated at a concentration of $1.0 \times 10^{5} \mathrm{cell} / \mathrm{s} / \mathrm{ml}$ in medium with $10 \%$ FBS. The cells were kept for $24 \mathrm{~h}$ in direct contact with the tested materials under the same culture conditions as described above. Images were obtained with an inverted light microscope (Axio Vert.A1, Zeiss) during the culture period and before fixation. ${ }^{24}$

\section{Results and discussion}

\section{Fiber Characterization}

Figure 1 shows the morphology of the materials studied by light microscopy at different magnifications (A1 and A2: PCL; B1 and B2: gelatin; C1 and C2: PCL/gelatin; scale bar = 200 and $50 \mu \mathrm{m}$, respectively). Regarding qualitative characteristics, the PCL/gelatin fibers were thicker and fiber spacing was smaller compared to pure PCL. The gelatin scaffold took on a non-porous form.
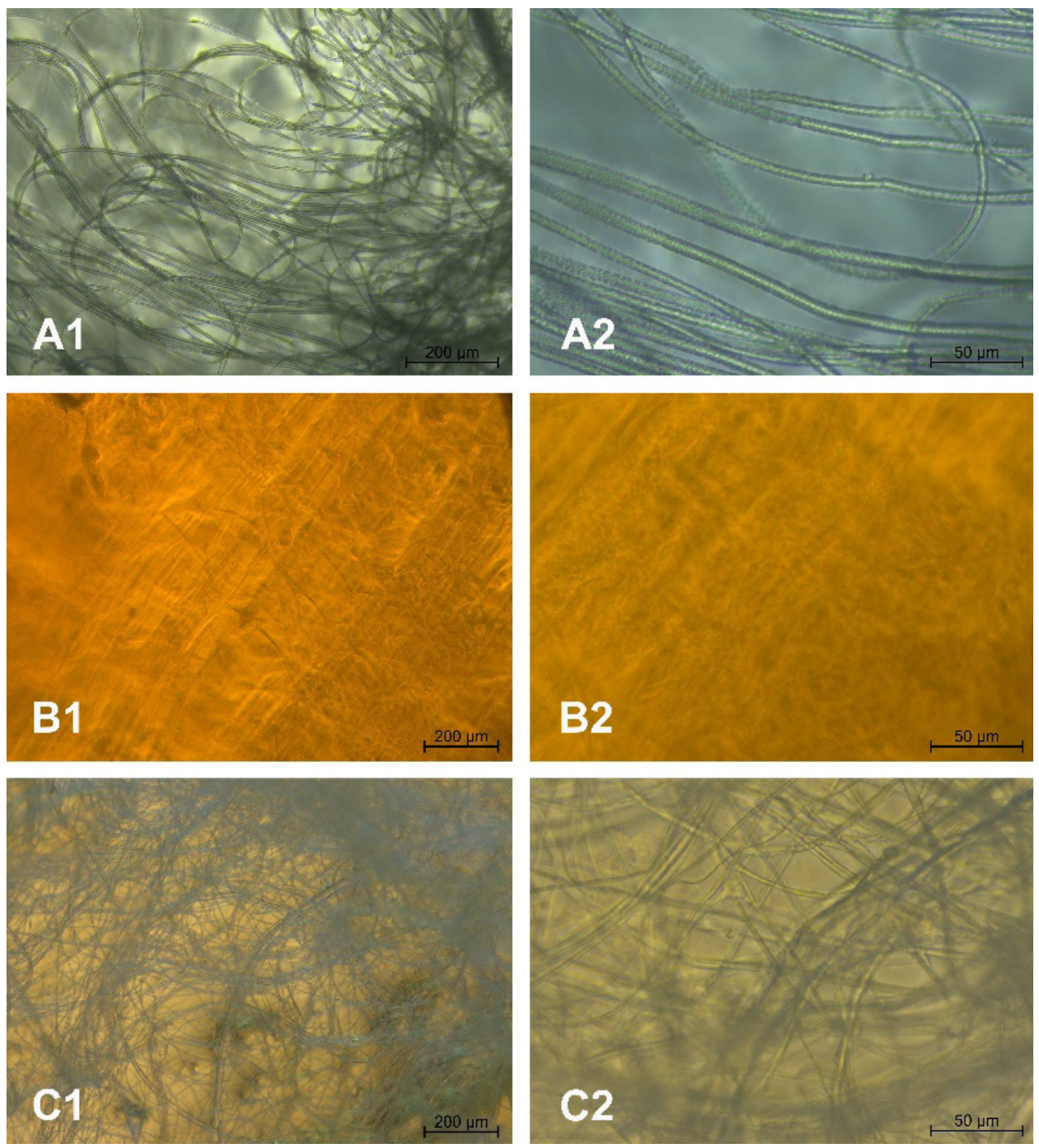

Figure 1 - Light microscopy analysis of the materials studied. A) PCL; B) gelatin; C) PCL/gelatin. Scale bar: $200 \mu \mathrm{m}$ for A1-C1; $50 \mu \mathrm{m}$ for A2-C2. 


\section{Giorno et al.}

The results of FTIR analysis of PCL, gelatin, and PCL/gelatin fibers are shown in Figure 2. For PCL, we observed a vibrational mode at $2947 \mathrm{~cm}^{-1}$, characteristic of asymmetric $\mathrm{CH}_{2}$ stretching, and at $2867 \mathrm{~cm}^{-1}$ corresponding to symmetric $\mathrm{CH}_{2}$ stretching. $\mathrm{AC}=0$ stretch can be seen at $1731 \mathrm{~cm}^{-1}$ and symmetric $\mathrm{C}-\mathrm{O}-\mathrm{O}$ stretching at $1176 \mathrm{~cm}^{-1} .25$ In the gelatin scaffold, we observed a peak at $3296 \mathrm{~cm}^{-1}$ characteristic of vibrational $\mathrm{O}-\mathrm{H}$ and $\mathrm{N}-\mathrm{H}$ stretch overlap; at $1535 \mathrm{~cm}^{-1}$ we have a C-N stretch and $\mathrm{N}-\mathrm{H}$ bending (amide II); at $1455 \mathrm{~cm}^{-1}$ we have $\mathrm{CH}_{2}$ bending; ${ }^{26}$ at $1242 \mathrm{~cm}^{-1}$ we have a C-N stretch and $\mathrm{N}-\mathrm{H}$ bending (amide III); at $1080 \mathrm{~cm}^{-1}$ we have a $\mathrm{C}-\mathrm{N}$ stretch and amide III. ${ }^{27}$ The same vibrational modes observed for the pure polymers (PCL and gelatin) were found for the PCL/gelatin scaffold, in addition to peaks at $1450 \mathrm{~cm}^{-1}$ and $1535 \mathrm{~cm}^{-1}$ (Figure 2). ${ }^{20,26}$

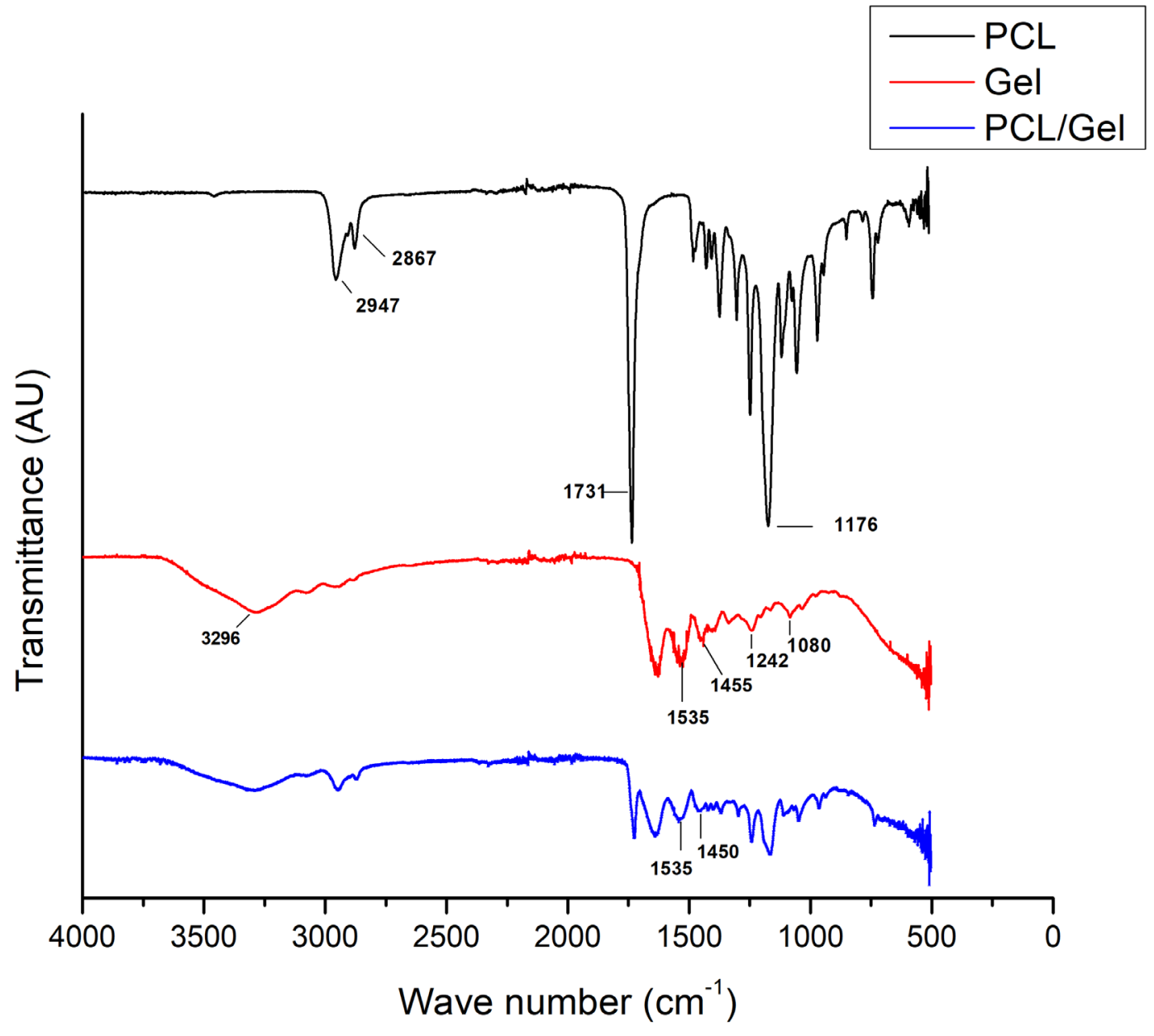

Figure 2 - FTIR analysis of PCL, gelatin and PCL/gelatin fibers.

\section{In Vitro Direct Contact Toxicity}

Figure 3 shows the phase-contrast microscopy analysis of the direct contact toxicity of Vero cells incubated for $24 \mathrm{~h}$ with the different materials (A: negative control; B: positive control; C: PCL; D: gelatin; E: PCL/gelatin; scale bar $=50 \mu \mathrm{m}$ ). The images show no contact toxicity.

The quantitative data did not reveal direct contact toxicity and we did not observe cellular changes promoted by the materials.

Depending on the severity of burn injury, which is classified based on the percentage of total body surface area involved, resistant materials are needed because the injury can extend beyond the dermis and can even expose bone components. ${ }^{1,2}$ We therefore chose to use PCL, which is bioresorbable and is classified as a temporary material. In addition to stimulating material-guided extracellular matrix production of the individual, PCL is later degraded, allowing tissue recovery. This material can confer structural stability to mechanical stresses of the system, prevent hydroelectrolyte losses, and minimize the body's susceptibility to infections. We combined PCL with gelatin to improve its features and interaction with human cells. It should be noted that uncrosslinked gelatin usually solubilizes in aqueous medium and is easily eliminated by the body in vivo. In addition, it is poorly resistant to mechanical stresses. 13,14,28,29

The advantages of the rotary jet spinning technique include its low cost, easy construction of the equipment, and high fiber yield. ${ }^{30}$

Many factors were considered to choose the most suitable cell type, including mitotic stability, function, and plasticity. Adequate laboratory practices ranging from the inoculation of the material to medium changes are also necessary since they can affect the results of the experiment. We used Vero cells in this study, which are recommended for the analysis of cytotoxicity and initial cell-cell interactions on biomaterials. ${ }^{24}$

Considering the satisfactory production of fibrous material, our results suggest that PCL/gelatin is a potential scaffold for tissue engineering. Our data were consisted with those reported by Vida et al. ${ }^{25}$ who studied PCL, PLLA, and PCL/PLLA fibers, and by Liu et al. ${ }^{19}$ in a review on gelatin. Cardoso et al. ${ }^{31}$ observed Vero cells spreading on PCL and PCL/chitosan fibers, a morphological pattern similar to that found in our study.

Taken together, the present results suggest that a fibrous scaffold, which structurally resembles extracellular matrix fibers, would represent a more physiological environment for cells. Further research will be conducted to confirm this suggestion. 

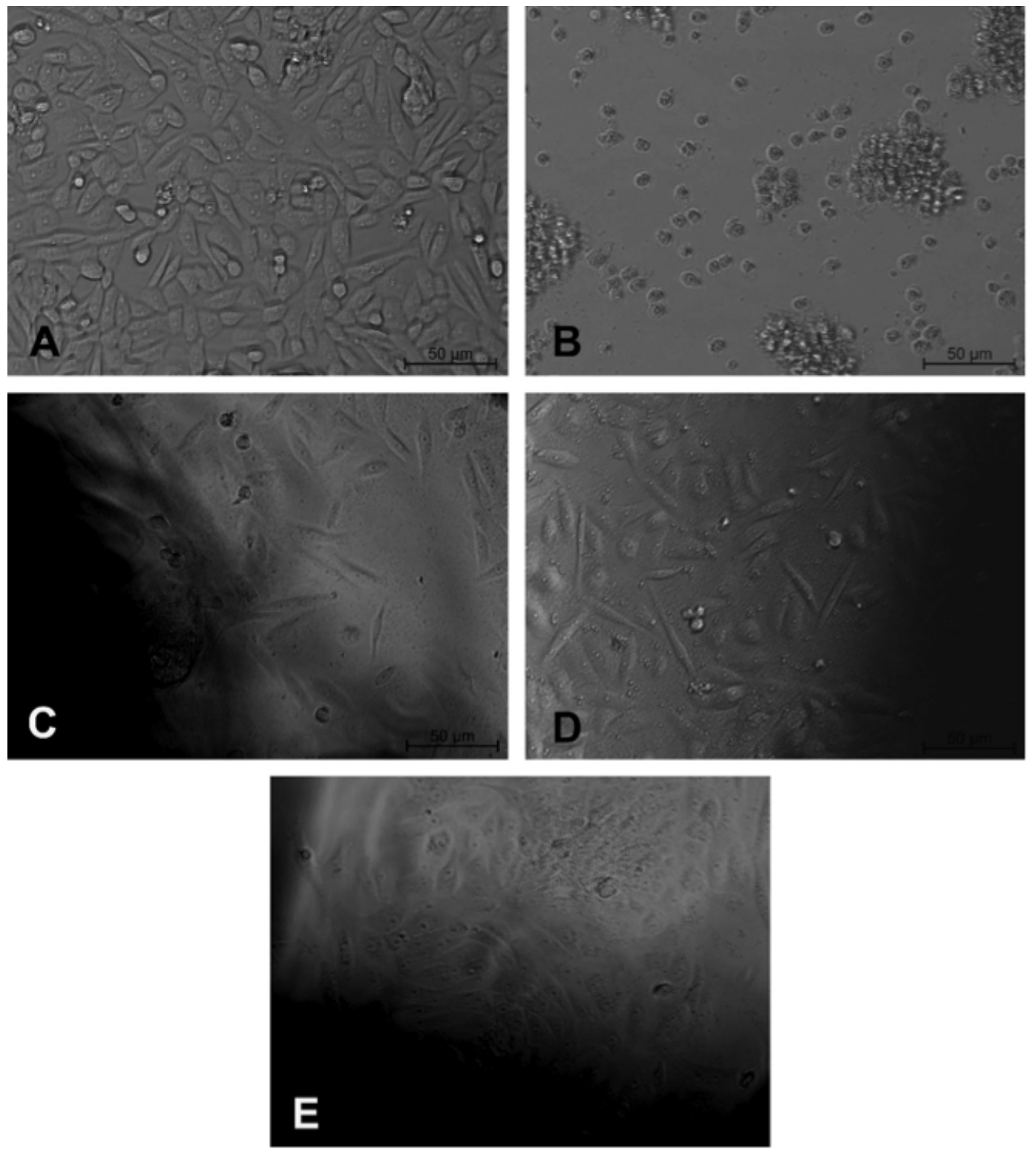

Figure 3 - Phase-contrast microscopy analysis of the direct contact toxicity of Vero cells in the different experimental groups after $24 \mathrm{~h}$ of incubation. A) Negative control; B) positive control; C) PCL; D) gelatin; E) PCL/gelatin. The images show no contact toxicity. Scale bar $=50 \mu \mathrm{m}$.

\section{Conclusion}

The rotary jet spinning technique permitted the production of fibers and the coating of gelatin on PCL fibers. The scaffolds were non-toxic and are promising for tissue engineering.

\section{References}

[1]. Associação Brasileira de Transplantes de Órgãos (ABTO) Registro brasileiro de transplantes (RBT). Ano XXIII No 3. (2017). Available at: <http:// www.abto.org.br/abtov03/Upload/file/RBT/2017/rbttrim3-leitura.pdf> Accessed 21 January 2018.

[2]. World Health Organization (WHO). Burns. World Health Organization: Media centre > Fact sheet > Updated August (2017). Available at: < http:// www.who.int/mediacentre/factsheets/fs365/en/> Accessed 21 January 2018.

[3]. Brito TSA. Tratamento de queimados graves com transplante de pele homóloga: revisão sistemática. 2016. 47f. Monografia (Graduação em Medicina) - Faculdade de Medicina da Bahia da Universidade Federal da Bahia. Salvador (Bahia) (2016).

[4]. Instituto Nacional de Traumatologia e Ortopedia (INTO) Abr. (2017). Available at: <https://www.into.saude.gov.br/area-de-imprensa/noticias/610-banco-de-pele-comeca-a-funcionar-no-into> Accessed 21 December 2017.

[5]. Paggiaro AO, Cathalá BS, Isaac C, Carvalho VF, Oliveira R, Gemperli R. Perfil epidemiológico do doador de pele do Banco de Tecidos do Hospital das Clínicas da Universidade de São Paulo. Rev Bras Queimaduras 16: 23-27 (2017). 
[6]. Park J. Biomaterials Science and Engineering. New York: Plenum Press, pp.193-233 (1984).

[7]. Liu C, Xia Z, Czernuszka JT. Design and development of three-dimensional scaffolds for tissue engineering. Chem Eng Res Des 85: 1051-1064 (2007).

[8]. Brasil. Conselho Nacional de Secretários de Saúde. Sistema Único de Saúde: Coleção para entender a gestão do SUS (2011), volume 1. Brasília: CONASS, 2011. p. 291. Available at: <http://www.conass.org.br/bibliotecav3/pdfs/coleca02011/livro 1.pdf> Accessed 30 January 2018.

[9]. Tenório M, Mello GA, Viana ALD. Políticas de fomento à ciência, tecnologia e inovação em saúde no Brasil e o lugar da pesquisa clínica. Ciênc. Saúde Coletiva 22: 1441-1454 (2017).

[10]. Giorno LP, Rodrigues LR, Santos Jr AR. Métodos avançados para tratamento de queimaduras: uma revisão. Rev Bras Queimaduras 17: 1-6 (2018).

[11]. Giorno LP, Rodrigues LR, Santos Jr AR. Biomedical graft technologies: An overview. Stem Cell Res Th 4: 135-141 (2019).

[12]. Casarin SA, Malmonge SM, Kobayashi M, Agnelli JAM. Study on in vitro degradation of bioabsorbable polymers poly (hydroxybutyrate-co-valerate) (PHBV) and poly (caprolactone) (PCL). J Biomater Nanobiotech 2: 207-215 (2011).

[13]. Qin X, Wu D. Effect of different solvents on poly(caprolactone) (PCL) electrospun nonwoven membranes. J Therm Anal Calorim 107: 1007-1013 (2012).

[14]. Gang Y, Xiao Z, Long H, Ma K, Zhang J, Ren X, Zhang J. Assessment of the characteristics and biocompatibility of gelatin sponge scaffolds prepared by various crosslinking methods. Sci Rep 8: 1616 (2018).

[15]. Zavaglia CA, Dias CGBT, Avila MAD, Lombello CB, Rodrigues LR, Perea GNR. Dispositivo modular de rotofiação, método de operação e uso. Número do registro: PI1020120084040, Instituição de registro: INPI - Instituto Nacional da Propriedade Industrial, Brasil, 2012.

[16]. Rigon GR. Matrizes de compósitos de PLDLA com hidroxiapatita obtidas por rotofiação para utilização em engenharia tecidual. 48f. Dissertção (Mestrado). Faculdade de Engenharia Mecânica, Universidade Estadual de Campinas. Campinas, SP: (2013).

[17]. Brito TAV. Preparação e Caracterização de Nanofibras da Blenda PLLA/PCL obtidas pelos Processos de Eletrofiação e Rotofiação. 90f. Dissertção (Mestrado). Faculdade de Engenharia Mecânica, Universidade Estadual de Campinas, Campinas (2013).

[18]. Badrossamay MR, Mcllwee HA, Goss JA, Parker KK. Nanofiber assembly by rotary jet-spinning. Nano Lett. 2010;10(6):2257-61.

[19]. Liu D, Nikoo M, Boran G, Zhou P, Regenstein JM. Collagen and gelatin. Annu Rev Food Sci Technol 6: 527-57 (2015).

[20]. Ferraraz DC, Rodrigues LR, Lombello CB. Avaliação da gelatina como arcabouço para células Vero. In: $8^{\circ}$ Simpósio de Instrumentação e Imagens Médicas (SIIM) e $07^{\circ}$ Simpósio de Processamento de Sinais (SPS), 2017, São Bernardo do Campo. $8^{\circ}$ Simpósio de Instrumentação e Imagens Médicas (SIIM) e o $7^{\circ}$ Simpósio de Processamento de Sinais (SPS), 2017.

[21]. Ryan J, Gerhold AR, Boudreau V, Smith L, Maddox, PS. Introduction to modern methods in light microscopy. In: Markaki Y, Harz H. (eds), Light Microscopy. Methods in Molecular Biology, vol 1563, New York: Humana Press, pp. 1-15, 2017 (2017).

[22]. Castro PAA. Espectroscopia de absorção no infravermelho em pele queimada: avaliação de potenciais biomarcadores para o reparo tecidual. Dissertação (Mestrado em Tecnologia Nuclear - Materiais) Instituto de Pesquisas Energéticas e Nucleares (IPEN) da Universidade de São Paulo (2018).

[23]. Kirkpatrick CJ. Biological testing of materials and medical devices - a critical view of current and proposed methodologies for biocompatibility testing: cytotoxicity in vitro. Reg Affairs 4: 13-32 (1992).

[24]. ISO 10993-5 I (E): Biological evaluation of medical devices. Part 5: Tests for cytotoxicity: in vitro methods (2009)

[25]. Vida TA, Motta AC, Santos Jr. AR, Cardoso GBC, Brito CC, Zavaglia CAC. Fibrous PCL/PLLA scaffolds obtained by rotary jet spinning and electrospinning. Mater Res 20: 910-916 (2017).

[26]. Zhuang C, Tao F, Cui Y. Anti-degradation gelatin films crosslinked by active ester based on cellulose. RSC Advances 5: 52183-52193 (2015).

[27]. Movasaghi, Z.; Rehman, S.; Rehman, I.U. Raman spectroscopy of biological tissues. App/ Spectrosc Rev 42: 493-541 (2007).

[28]. Woodruff MA, Hutmacher DW. The return of a forgotten polymer - Polycaprolactone in the 21st century. Prog Polym Sci 35:1217-1256 (2010)

[29]. Cipitria A, Skelton A, Dargaville TR, Dalton PD, Hutmacher DW. Design, fabrication and characterization of PCL electrospun scaffolds - a review. J Mater Chem 21: 9419-9453 (2011). 
Fibrous PCL scaffolds as tissue substitutes...

[30]. Rogalski JJ, Bastiaansen CW, Peijs T. Rotary jet spinning review - a potential high yield future for polymer nanofibers. Nanocomposites 3: 97-121 (2017).

[31]. Cardoso GB, Machado-Silva AB, Sabino M, Santos Jr AR, Zavaglia CA. Novel hybrid membrane of chitosan/poly ( $\square$-caprolactone) for tissue engineering. Biomatter 4: e29508 (2014). 